\title{
De Individuele Werkprestatie Vragenlijst (IWPV): interne consistentie, construct validiteit en normering
}

\author{
Linda Koopmans, ${ }^{1,2,4}$ Claire Bernaards, ${ }^{1,2}$ Vincent Hildebrandt, ${ }^{1,2}$ Riekie de Vet, ${ }^{3}$ Allard van der Beek ${ }^{1,4}$
}

\begin{abstract}
Het meten van individuele werkprestatie, gedefinieerd als "gedragingen of acties van werknemers die relevant zijn voor de doelstelling van de organisatie", blijkt lastig. Tot op heden ontbrak een geschikte vragenlijst om individuele werkprestatie te meten in een generieke, overwegend gezonde, werknemerspopulatie. In het huidige artikel wordt de Individuele Werkprestatie Vragenlijst (IWPV) geïntroduceerd. De IWPV is gebaseerd op een conceptueel model bestaande uit de drie dimensies taakprestatie, contextuele prestatie, en contraproductief werkgedrag. De factor structuur en interne consistentie van de IWPV schalen blijken goed te zijn. Ook de construct validiteit kan als redelijk goed worden geclassificeerd. Ten slotte worden normscores per type werk gepresenteerd. De IWPV is al met al een valide instrument om de relevante dimensies van individuele werkprestatie op een korte, volledige, en generieke manier (in alle typen werk en voor werknemers met en zonder gezondheidsklachten) te meten.
\end{abstract}

Trefwoorden: werkprestatie, productiviteit, vragenlijst, schaal

\section{INLEIDING}

Werkprestatie is niet alleen een veel gebruikt woord binnen bedrijven, maar krijgt ook veel aandacht in wetenschappelijk onderzoek. Talloze studies naar werkprestatie zijn verricht vanuit diverse invalshoeken, waarbij werkprestatie vanuit zowel bedrijfsniveau als individueel niveau bekeken kan worden. De bedrijfskunde houdt zich voornamelijk bezig met hoe men de prestatie van werknemers kan optimaliseren door de bedrijfsprocessen te optimaliseren. In de arbeids-en organisatie psychologie ligt de interesse voornamelijk bij voorspellers van werkprestatie, zoals werkorganisatie, bevlogenheid, tevredenheid met het werk, en persoonlijkheidskenmerken. De arbeidsepidemiologie richt zich daarentegen vooral op samenhang tussen die gezondheidsklachten, ziekteverzuim en prestatieverlies. Ondanks de vele studies naar werkprestatie, is er pas recent meer aandacht gekomen voor het definiëren van het construct van individuele werkprestatie, en het begrijpen van de onderliggende structuur hiervan. ${ }^{1,2}$ Want wat is individuele werkpres-

${ }^{1}$ Body@Work, onderzoekscentrum TNO, Leiden, VU medisch centrum (VUmc) en Vrije Universiteit (VU), Amsterdam

2 TNO, expertise centrum Life Style, Leiden

${ }^{3}$ VU medisch centrum, afdeling Epidemiologie en Biostatistiek, Amsterdam

${ }^{4}$ VU medisch centrum, afdeling Sociale Geneeskunde, Amsterdam tatie eigenlijk precies? Waar bestaat het uit? En hoe kunnen we het vervolgens meten? Voordat we individuele werkprestatie op een betrouwbare en valide kunnen meten, is eerst een gegronde definitie en conceptueel model nodig.

\section{Het begrip individuele werkprestatie}

De algemeen geaccepteerde definitie van individuele werkprestatie is "gedragingen of acties van werknemers die relevant zijn voor de doelstelling van de organisatie". 3 it betekent dat individuele werkprestatie (IWP) zich richt op gedragingen of acties van een werknemer, en niet zozeer op de resultaten hiervan. Daarnaast moet het gedrag onder de controle van het individu zijn, waardoor gedragingen die bepaald worden door de omgeving geëxcludeerd worden (bijvoorbeeld technische problemen). ${ }^{2}$

Om IWP te kunnen meten, moeten we meer te weten komen over de onderliggende structuur. Want uit welke gedragingen of acties bestaat het nu precies? Uit de literatuur blijkt dat het eerste onderdeel van individuele werkprestatie taakprestatie is. Taakprestatie kan gedefinieerd worden als de kundigheid waarmee individuen centrale werktaken uitvoeren. ${ }^{3}$ Gedragingen die onder taakprestatie vallen zijn bijvoorbeeld het plannen en organiseren van het werk, resultaatgericht werken, en efficiënt werken. ${ }^{4,5}$ 
Naast taakprestatie zijn ook contextuele prestatie en contraproductief werkgedrag belangrijke onderdelen van werkprestatie. ${ }^{2,6,7}$ Contextuele prestatie kan gedefinieerd worden als een verzameling van gedragingen die de organisatorische, sociale, en psychologische omgeving ondersteunen waarin de centrale werktaken worden uitgevoerd. ${ }^{8}$ Hierbij kan bijvoorbeeld gedacht worden aan initiatief nemen, samenwerken met anderen, en het aangaan van uitdagende werktaken. ${ }^{5}$ Contraproductief werkgedrag kan gedefinieerd worden als gedragingen die schade toebrengen aan het welzijn van de organisatie. ${ }^{2}$ Het omvat bijvoorbeeld het vertonen van buitensporige negativiteit, het schade toebrengen aan collega's en/of de organisatie. ${ }^{5}$

\section{Meten van individuele werkprestatie}

Er zijn veel verschillende vragenlijsten ontwikkeld om individuele werkprestatie te meten. Vanuit de arbeids- en organisatiepsychologie zijn voornamelijk vragenlijsten ontwikkeld die een onderdeel van individuele werkprestatie meten. Zo zijn er verschillende vragenlijsten ontwikkeld om taakprestatie (zie bijvoorbeeld ${ }^{9}$ ), contextuele prestatie (zie bijvoorbeeld ${ }^{10}$ ) of contraproductief gedrag (zie bijvoorbeeld ${ }^{11}$ ) te meten. Vanuit de arbeidsepidemiologie zijn vragenlijsten ontwikkeld die verlies in werkprestatie door gezondheidsklachten (ook wel absenteïsme en/of presenteïsme genoemd) meten. Bekende vragenlijst zijn bijvoorbeeld de Work Productivity and Impairment Questionnaire, ${ }^{12}$ de Work Limitations Questionnaire, ${ }^{13}$ en de WHO Health and Performance Questionnaire. ${ }^{14}$ Voor reviews van meetinstrumenten vanuit de arbeidsepidemiologie, zie Lofland, Pizzi \& Frick $^{15}$ en Mattke et al. ${ }^{16}$

Veel van deze vragenlijsten zijn ontwikkeld voor een specifiek type werk of voor werknemers met gezondheidsklachten. Een gevolg hiervan is dat geen van de vragenlijsten geschikt is voor generiek gebruik, dat wil zeggen voor werknemers in allerlei beroepen en voor werknemers met en zonder gezondheidsklachten. Daarnaast is opvallend dat geen van de vragenlijsten alle relevante onderdelen van individuele werkprestatie tezamen meet. Het gevolg hiervan is dat niet het gehele spectrum van individuele werkprestatie gedragingen wordt gemeten, maar vaak slechts één onderdeel. Het combineren van verschillende vragenlijsten zou in principe niet erg zijn, mits overeenstemming is over wat en hoe men precies meet. Dit lijkt echter niet het geval te zijn. Vragenlijsten die dezelfde dimensie van IWP meten, zijn vaak verschillend geoperationaliseerd: ze vragen naar verschillende gedragingen, en er lijkt dus geen consensus te zijn over hoe men de dimensies van IWP moet meten. Aan de andere kant vertonen vragenlijsten die juist wél een andere dimensie van IWP proberen te meten, soms weer overlappende vragen. Zo bevatten bijvoorbeeld vragenlijsten die respectievelijk contextuele prestatie versus contraproductief werkgedrag trachten te meten, vragen over dezelfde gedragingen (bijvoorbeeld "geen extra pauzes nemen" bij contextuele prestatie, en "extra pauzes nemen" bij contraproductief gedrag). Concluderend lijkt geen van de bestaande vragenlijsten optimaal geschikt voor gebruik in een generieke, overwegend gezonde, werknemerspopulatie.

\section{De Individuele Werkprestatie Vragenlijst}

Om te komen tot een kort, volledig en generiek inzetbaar instrument voor het meten van IWP, is de Individuele Werkprestatie Vragenlijst (IWPV; IWPQ in het Engels) ontwikkeld. ${ }^{17,18}$ De ontwikkeling van de IWPV is gebaseerd op een uitgebreid literatuuronderzoek, waarbij alle relevante dimensies van individuele werkprestatie vanuit verschillende disciplines zijn geïntegreerd in één overkoepelend conceptueel model. ${ }^{6}$ Hierdoor biedt de IWPV onderzoekers een manier om het gehele spectrum van individuele werkprestatie (taakprestatie, contextuele prestatie, en contraproductief werkgedrag) te meten met één korte vragenlijst.

De drie schalen van de IWPV zijn geoperationaliseerd op basis van het conceptuele model en een consensus studie onder experts. ${ }^{5}$ Mede hierdoor hebben de IWPV schalen een goede content validiteit, is de inhoud van de schalen relevant voor alle typen werk, en is er geen overlappende inhoud tussen de schalen.

Daarnaast is de IWPV ontwikkeld en verfijnd met behulp van Rasch analyse ${ }^{19}$ in een populatie waarin diverse typen werk voorkwam. Het gebruik van Rasch analyse heeft er voor gezorgd dat de IWPV voldoet aan belangrijke meeteigenschappen, zoals unidimensionele schalen die alle niveaus van IWP kunnen meten (van een lage tot een hoge werkprestatie). Door het gebruik van een brede werknemerspopulatie kon worden bekeken of de IWPV geschikt is voor werknemers met allerlei typen werk (van bouwvakkers tot kantoormedewerkers) en het dus als generieke (d.w.z. niet beroepsspecifieke) vragenlijst gebruikt kan worden. Het uitgebreide ontwikkelingsproces dat vooraf is gegaan aan de IWPV zal in dit artikel niet verder beschreven worden, maar staat uitgebreid gerapporteerd in Koopmans et al. 5,17,18

Het huidige artikel beschrijft de factor structuur en interne consistentie van de IWPV schalen en de construct 
validiteit van de IWPV. Tevens worden normscores gepresenteerd voor de IWPV.

\section{METHODE}

\section{De Individuele Werkprestatie Vragenlijst (IWPV)}

De IWPV bestaat uit 18 vragen verdeeld over de drie dimensies van IWP (zie tabel 1). De taakprestatie schaal bestaat uit vijf vragen (zoals "In de afgelopen drie maanden lukte het mij om mijn werk zo te plannen, dat het werk op tijd af was"), de contextuele prestatie schaal uit acht vragen (zoals "In de afgelopen drie maanden heb ik uitdagende werktaken op me genomen, als die er waren"), en de contraproductieve schaal uit vijf vragen (zoals "In de afgelopen drie maanden heb ik geklaagd over onbelangrijke zaken op mijn werk"). De IWPV hanteert bij alle drie de dimensies een 5-puntsschaal ("zelden" tot "altijd" voor taak- en contextuele prestatie, en "nooit" tot "vaak" voor contraproductief werkgedrag).

Schaalscores van de IWPV kunnen berekend worden door de scores op de items in de schaal op te tellen, en te delen door het aantal items in de schaal. De IWPV resulteert dus in drie schaalscores op een schaal van 0 tot 4 , waarbij hogere scores staan voor een hogere taak- en contextuele prestatie, en hoger contraproductief werkgedrag.

\section{Onderzoekspopulatie}

Deelnemers zijn door een internetpanelbureau geworven uit een grote, representatieve steekproef van Nederlandse werknemers. De deelnemers waren afkomstig uit drie typen werk: fysiek werk ('blue collar,' bijvoorbeeld machinist of timmerman), dienstverlenend werk ('pink collar,' bijvoorbeeld kapper of verpleegkundige), en mentaal werk ('white collar,' bijvoorbeeld architecten en wetenschappers). De beroepen zijn door het internetpanelbu- reau onderverdeeld in fysiek werk, mentaal werk en dienstverlenend werk op basis van de Standaard Beroepenclassificatie van het Centraal Bureau voor Statistiek (CBS).

\section{Interne consistentie}

De IWPV is gebaseerd op een conceptueel model met drie dimensies van IWP: taakprestatie, contextuele prestatie, en contraproductief werkgedrag. Om te onderzoeken of deze verwachte driedimensionale structuur bevestigd wordt, is factoranalyse (principale componenten) met varimax rotatie uitgevoerd in SPSS 20. De interne consistentie van elke schaal is berekend met Cronbach's alpha. ${ }^{20}$

\section{Construct validiteit}

Validiteit refereert naar de mate waarin een instrument meet wat deze beoogt te meten. ${ }^{21}$ Met construct validiteit wordt onderzocht of de scores op het instrument zoals verwacht samenhangen met scores op andere constructen. In de huidige studie zijn twee typen construct validiteit bepaald, namelijk de convergente en discriminante validiteit. Voor convergente validiteit zijn de correlaties van de IWPV scores met de scores op presenteïsme (verlies in prestatie door bijvoorbeeld gezondheidsproblemen, waarbij men wel op het werk is) en werkbevlogenheid bepaald. Voor discriminante validiteit is bepaald of groepen met hoge versus lage werktevredenheid, en groepen met een goede versus slechte gezondheid, verschillend scoren op de IWPV.

Presenteïsme is gemeten met twee vragen van de Health and Performance Questionnaire (HPQ). ${ }^{14}$ De werknemer wordt gevraagd om een algemeen oordeel van de eigen werkprestatie, en om een algemeen oordeel van de werkprestatie van collega's met vergelijkbaar werk. Op basis hiervan kan de relatieve werkprestatie van mede-

Tabel 1. De vragen van de Individuele Werkprestatie Vragenlijst (IWPV), met gemiddelden (M) en standaard deviaties (SD) op een o-4 Schaal.

\begin{tabular}{|c|c|c|c|}
\hline Schaal & & M & SD \\
\hline \multicolumn{4}{|c|}{ Taakprestatie (TP) schaal } \\
\hline $\mathrm{TP}_{1}$ & Lukte het mij om mijn werk zo te plannen, dat het werk op tijd af was. & 2,80 & 0,95 \\
\hline TP2 & Hield ik voor ogen welk resultaat ik moest behalen met mijn werk. & 2,47 & 0,98 \\
\hline $\mathrm{TP}_{3}$ & Lukte het mij om hoofdzaken van bijzaken te scheiden. & 3,11 & 0,81 \\
\hline TP4 & Lukte het mij om mijn werk goed uit te voeren met zo min mogelijk tijd en inspanning. & 2,83 & 0,82 \\
\hline $\mathrm{TP}_{5}$ & Heb ik een optimale planning gemaakt. & 2,32 & 1,00 \\
\hline \multicolumn{4}{|c|}{$\begin{array}{l}\text { Contextuele prestatie (CP) schaal } \\
\text { In de afgelopen } 3 \text { maanden... }\end{array}$} \\
\hline $\mathrm{CP}_{1}$ & Ben ik uit mezelf met nieuwe taken begonnen, als mijn oude taken af waren. & 2,24 & 1,09 \\
\hline $\mathrm{CP} 2$ & Heb ik uitdagende werktaken op me genomen, als die er waren. & 2,57 & 1,13 \\
\hline $\mathrm{CP}_{3}$ & Heb ik gewerkt aan het bijhouden van mijn vakkennis. & 2,32 & 1,08 \\
\hline $\mathrm{CP}_{4}$ & Heb ik gewerkt aan het bijhouden van mijn werkvaardigheden. & 2,28 & 1,15 \\
\hline $\mathrm{CP}_{5}$ & Kwam ik met creatieve oplossingen voor nieuwe problemen. & 2,42 & 1,02 \\
\hline CP6 & Heb ik extra verantwoordelijkheden op me genomen. & 2,31 & 0,98 \\
\hline $\mathrm{CP} 7$ & Zocht ik steeds naar nieuwe uitdagingen in het werk. & 2,12 & 1,10 \\
\hline CP8 & Had in een actieve inbreng in werkoverleg of vergaderingen. & 2,25 & 1,20 \\
\hline \multicolumn{4}{|c|}{$\begin{array}{l}\text { Contraproductief werkgedrag (CWB) schaal } \\
\text { In de afgelopen } 3 \text { maanden... }\end{array}$} \\
\hline CWB1 & Heb ik geklaagd over onbelangrijke zaken op mijn werk. & 0,97 & 0,85 \\
\hline CWB2 & Heb ik problemen groter gemaakt dan ze waren op mijn werk. & 0,71 & 0,76 \\
\hline CWB3 & Heb ik me gericht op de negatieve kanten van een werksituatie, in plaats van op de positieve kanten. & 1,10 & 0,86 \\
\hline CWB4 & Heb ik gepraat met collegás over de negatieve kanten van mijn werk. & 1,56 & 1,02 \\
\hline CWB5 & Heb ik gepraat met mensen van buiten de organisatie over de negatieve kanten van mijn werk. & 1,21 & 1,05 \\
\hline
\end{tabular}


Tabel 2. Deelnemersgegevens (\%) en IWPV schalen (gemiddelde (M) en standaard deviatie (SD)).

\begin{tabular}{|c|c|c|c|c|}
\hline & $\begin{array}{l}\text { Totale groep } \\
(n=1424)\end{array}$ & $\begin{array}{l}\text { Fysiek werk } \\
(n=442)\end{array}$ & $\begin{array}{l}\text { Dienstverlenend werk } \\
(n=540)\end{array}$ & $\begin{array}{l}\text { Mentaal werk } \\
(n=442)\end{array}$ \\
\hline $\begin{array}{l}\text { Geslacht (\% vrouw) } \\
\text { Leeftijd (\%) }\end{array}$ & 42,4 & 14,0 & 65,6 & 42,5 \\
\hline 17-34 jaar & 22,2 & 19,9 & 23,0 & 23,5 \\
\hline 35-44 jaar & 26,2 & 22,6 & 30,7 & 24,2 \\
\hline 45-54 jaar & 29,6 & 29,4 & 28,9 & 30,5 \\
\hline $\begin{array}{l}55-69 \text { jaar } \\
\text { Opleidingsniveau (\%) }\end{array}$ & 22,0 & 28,1 & 17,4 & 21,8 \\
\hline Basisonderwijs & 3,1 & 5,4 & 3,3 & 0,5 \\
\hline Voortgezet onderwijs & 38,1 & 54,5 & 40,7 & 18,6 \\
\hline Middelbaar beroepsonderwijs & 29,7 & 34,4 & 34,4 & 19,2 \\
\hline Hoger onderwijs & 28,5 & 4,8 & 21,3 & 61,1 \\
\hline $\begin{array}{l}\text { Onbekend } \\
\text { IWPV (0-4) (M (SD)) }\end{array}$ & 0,6 & 0,9 & 0,2 & 0,7 \\
\hline Taakprestatie & $2,71(0,66)$ & $2,82(0,65)$ & $2,71(0,66)$ & $2,59(0,63)$ \\
\hline Contextuele prestatie & $2,31(0,77)$ & $2,30(0,82)$ & $2,31(0,76)$ & $2,34(0,72)$ \\
\hline Contraproductief werkgedrag & $1,11(0,67)$ & $1,03(0,63)$ & $1,09(0,71)$ & $1,21(0,66)$ \\
\hline
\end{tabular}

werkers worden bepaald. Beide vragen worden beantwoord op een schaal van 0 ("slechtst mogelijke werkprestatie") tot 10 ("best mogelijke werkprestatie").

Werkbevlogenheid is gemeten met de 9-item Utrecht Work Engagement Scale (UWES-9). ${ }^{22}$ De UWES resulteert in één totaalscore en drie schaalscores (vitaliteit, toewijding en absorptie) op een schaal van 0 ("nooit") tot 6 ("altijd").

Algehele werktevredenheid is gemeten met één beoordeling op een schaal van 0 ("heel ontevreden") tot 10 ("heel tevreden"). Groepen zijn gemaakt op basis van kwartielen. Algehele gezondheid is gemeten met één algemene beoordeling op een schaal van 0 ("heel slecht") tot 10 ("heel goed"). Groepen zijn gemaakt op basis van kwartielen.

\section{Hypothesen}

Hypothesen met betrekking tot convergente validiteit:

1 De algemene beoordeling van de eigen werkprestatie hangt sterk positief samen met de IWPV taakprestatie en contextuele prestatie scores $(r>0,50)$, en sterk negatief met de contraproductieve score $(r<-0,50)$.

2 De eigen werkprestatie ten opzichte van die van collega's hangt zwak positief samen met de IWPV taakprestatie en contextuele prestatie scores $(r<0,30)$, en zwak negatief met de contraproductieve score $(r>$ $-0,30)$.

3 Werkbevlogenheid hangt matig positief samen met de IWPV taakprestatie en contextuele prestatie scores $(r=$ $0,30-0,50)$, en matig negatief met de contraproductieve score $(r=-0,30--0,50)$.

Hypothesen met betrekking tot discriminante validiteit:

1 Werknemers met een hoge werktevredenheid scoren significant hoger op taakprestatie en contextuele prestatie, en significant lager op contraproductief werkgedrag, dan werknemers met een lage werktevredenheid.

2 Werknemers met een goede gezondheid scoren significant hoger op taakprestatie en contextuele prestatie, en significant lager op contraproductief werkgedrag, dan werknemers met een slechte gezondheid.

\section{RESULtATEN}

\section{Deelnemers}

Aan dit onderzoek namen 1424 Nederlandse, werkende deelnemers deel. Zie tabel 1 voor een overzicht van de IPWV vragen met hun gemiddelde score en standaard deviatie. De deelnemers varieerden in leeftijd van 17 tot 69 jaar, met een gemiddelde leeftijd van 44,4 jaar. Van de deelnemers was $42,4 \%$ vrouw. 442 Deelnemers deden fysiek werk, 540 deden dienstverlenend werk, en 442 deden mentaal werk. In tabel 2 staan verdere deelnemersgegevens beschreven, evenals de gemiddelde (en standaard deviatie) scores op de IWPV schalen.

\section{Interne consistentie}

Op basis van factoranalyse bleek de IWPV uit drie dimensies te bestaan, waarbij de items $>0,40$ op de verwachtte dimensies laadden. Dit driedimensionale model was generaliseerbaar voor alle typen werk. De interne consistentie van de schalen was goed. De waarden van Cronbach's alpha varieerden tussen de 0,78 en 0,85 (tabel 3 ). De correlatie van de taakprestatie schaal met de contextuele en contraproductieve schaal bedroeg 0,48 respectievelijk -0,26. De correlatie tussen de contextuele en contraproductieve schaal bedroeg $-0,09$.

\section{Construct validiteit}

In tabel 4 zijn de correlaties tussen de Individuele Werkprestatie Vragenlijst schalen te zien. Vervolgens zijn de verwachte en gevonden correlaties van de IWPV schalen met de andere onderzochte constructen te zien. De algemene beoordeling van de eigen werkprestatie (absoluut presenteïsme) liet een matig positieve correlatie zien met de IWPV taakprestatie en contextuele prestatie schalen $(r$ $=0,39$ respectievelijk 0,33 ), en een zwak negatieve correlatie met de contraproductieve schaal $(r=-0,16)$. De

Tabel 3. Interne consistentie van de IWPV schalen.

\begin{tabular}{ll}
\hline Schaal & Cronbach's alpha \\
\hline Taakprestatie & 0,78 \\
Contextuele prestatie & 0,85 \\
Contraproductief werkgedrag & 0,79 \\
\hline
\end{tabular}


eigen werkprestatie ten opzichte van die van collega's (relatief presenteïsme) liet een zwak positieve correlatie zien met alle IWPV schalen $(r=0,07-0,11)$.

Tevens zijn de IWPV scores vergeleken met scores op werkbevlogenheid. Werkbevlogenheid, alsmede de afzonderlijke schalen van werkbevlogenheid, vertoonde een matig positieve correlatie met de IWPV taakprestatie en contextuele prestatie schalen $(r=0,29-0,43)$, en een matig tot zwak negatieve correlatie met de contraproductieve schaal $(r=-0,40--0,23)$.

Tot slot is gekeken of relevante groepen te onderscheiden waren op IWPV scores. Groepen gebaseerd op werktevredenheid verschilden significant in taakprestatie $(F(3,1420)=66,49, p<0,001)$, contextuele prestatie $(F(3,1420)=49,04, p<0,001)$, en contraproductief werkgedrag $(F(3,1420)=86,62, p<0,001)$. Werknemers met een hogere werktevredenheid vertoonden hogere taakprestatie, hogere contextuele prestatie, en lager contraproductief werkgedrag dan werknemers met een lagere werktevredenheid. Alle kwartielen verschilden significant van elkaar (zie figuur 1).

Tevens bleek dat groepen gebaseerd op gezondheid significant verschilden in taakprestatie $(F(3,1420)=$ $35,71, p<0,001)$, contextuele prestatie $(F(3,1420)=$ $29,61, p<0,001)$, en contraproductief werkgedrag ( $F(3$, $1420)=26,40, p<0,001)$. Werknemers met een betere gezondheid vertoonden hogere taakprestatie, hogere contextuele prestatie, en lager contraproductief werkge- drag dan werknemers met een slechtere gezondheid. Bijna alle kwartielen verschilden significant van elkaar (zie figuur 1).

\section{Normscores per type werk}

Onze resultaten zijn verkregen in een grote steekproef uit de Nederlandse werkende bevolking. Daarom kunnen de scores uit het huidige onderzoek gebruikt worden als normscores. De normeringen wordt per type werk gepresenteerd (zie tabel 5). Tot slot kunnen de IWPV scores geïnterpreteerd worden op een schaal van 'heel laag' tot 'heel hoog,' gebaseerd op percentielen (zie ook tabel 5).

\section{Discussie}

Het doel van het huidige artikel was om de recent ontwikkelde Individuele Werkprestatie Vragenlijst (IWPV) te introduceren, en om daarvan de factor structuur, interne consistentie, construct validiteit, en normering te beschrijven. De verwachte factor structuur van de IWPV werd bevestigd, waarbij individuele werkprestatie bestaat uit de drie dimensies taakprestatie, contextuele prestatie, en contraproductief werkgedrag. De interne consistentie van de drie schalen was goed tot zeer goed.

\section{Validiteit - relatie met andere constructen}

De IWPV relateerde grotendeels zoals verwacht aan andere constructen, en maakte onderscheid tussen relevante groepen. Ten eerste bleken de IWPV scores matig positief

Tabel 4. Correlaties tussen de Individuele Werkprestatie Vragenlijst schalen en verwachte en gevonden correlaties met absoluut en relatief presenteïsme en werkbevlogenheid (convergente validiteit).

Individuele Werkprestatie Vragenlijst

Taakprestatie Contextuele prestatie

$\begin{array}{lll}- & 0,45 & -0,25 \\ 0,45 & - & -0,09 \\ -0,25 & -0,09 & -\end{array}$

IWPV schaalcorrelaties

Taakprestatie

Contextuele prestatie

Contraproductief werkgedrag

\section{Absoluut presenteïsme}

Taakprestatie

Contextuele prestatie

Contraproductief werkgedrag

Verwachte correlatie

Sterk $(>0,50)$

Sterk $(>0,50)$

Sterk $(<-0,50)$

Relatief presenteïsme

Taakprestatie

Contextuele prestatie

Contraproductief werkgedrag

Zwak $(<0,30)$

Zwak $(<0,30)$

Zwak (>-0,30)

Matig (0,30-0,50)

Matig $(0,30-0,50)$

Matig $(-0,30--0,50)$
Gevonden correlatie

Matig $(0,39)$

Matig $(0,33)$

Zwak $(-0,16)$

\section{Contraproductief werkge-}

drag

Zwak (o,09)

Zwak $(0,11)$

Zwak (0,07)

Werkbevlogenheid (totaalscore)

Contextuele prestatie

Contraproductief werkgedrag

Tabel 5. Normering van de IWPV taakprestatie (TP), contextuele prestatie (CP) en contraproductief werkgedrag (CWB) scores (schaal o-4) per type werk, en interpretatie op basis van percentielen $(p)$.

\begin{tabular}{|c|c|c|c|c|c|c|c|c|c|}
\hline & \multicolumn{3}{|l|}{ Fysiek werk } & \multicolumn{3}{|c|}{ Dienstverlenend werk } & \multicolumn{3}{|c|}{ Mentaal werk } \\
\hline & TP & $\mathrm{CP}$ & CWB & TP & $\mathrm{CP}$ & CWB & TP & $\mathrm{CP}$ & CWB \\
\hline Gemiddelde score & 2,77 & 2,30 & 1,03 & 2,68 & 2,31 & 1,09 & 2,55 & 2,34 & 1,21 \\
\hline Standaarddeviatie & 0,62 & 0,82 & 0,63 & 0,63 & 0,76 & 0,71 & 0,63 & 0,72 & 0,66 \\
\hline \multicolumn{10}{|l|}{ Interpretatie } \\
\hline Heel laag (1op) & $\leq 2,00$ & $\leq 1,25$ & $\leq 0,20$ & $\leq 1,83$ & $\leq 1,25$ & $\leq 0,00$ & $\leq 1,83$ & $\leq 1,37$ & $\leq 0,40$ \\
\hline Laag (p25) & $2,01-2,49$ & $1,26-1,74$ & $0,21-0,59$ & $1,84-2,32$ & $1,26-1,74$ & $0,01-0,59$ & $1,84-2,16$ & $1,38-1,87$ & $0,41-0,79$ \\
\hline Gemiddeld (p5o) & $2,50-3,16$ & $1,75-2,99$ & $0,60-1,39$ & $2,33-2,99$ & $1,75-2,87$ & $0,60-1,59$ & $2,17-2,99$ & $1,88-2,87$ & $0,80-1,59$ \\
\hline Hoog (75p) & $3,17-3,49$ & $3,00-3,24$ & $1,40-1,79$ & $3,00-3,49$ & $2,88-3,12$ & $1,60-1,99$ & $3,00-3,32$ & $2,88-3,24$ & $1,60-1,99$ \\
\hline Heel hoog (9op) & $\geq 3,50$ & $\geq 3,25$ & $\geq 1,80$ & $\geq 3,50$ & $\geq 3,13$ & $\geq 2,00$ & $\geq 3,33$ & $\geq 3,25$ & $\geq 2,00$ \\
\hline
\end{tabular}



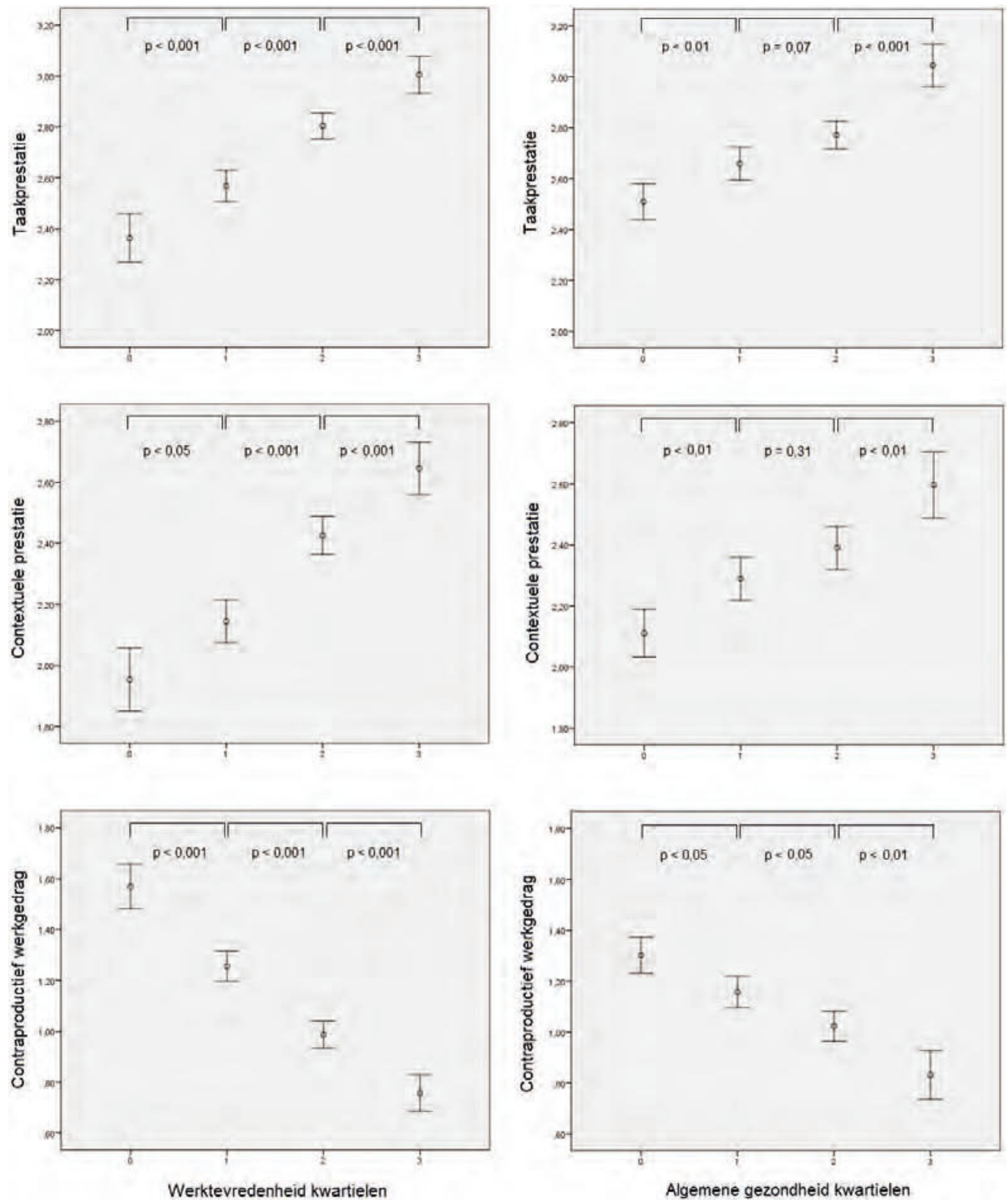

Figuur 1. Discriminante validiteit van de IWPV schalen (schaal o-4) voor kwartielen op basis van werktevredenheid en kwartielen op basis van algemene gezondheid (de plots tonen de gemiddelde score per kwartiel en het bijbehorende 95\% betrouwbaarheidsinterval).

samen te hangen met een algemene beoordeling van de eigen werkprestatie (absoluut presenteïsme). Deze samenhang was minder sterk dan verwacht. Deze zwakkere samenhang kan deels verklaard worden doordat in de huidige studie slechts twee vragen uit de HPQ zijn afgenomen en de priming vragen, die standaard in de HPQ worden gevraagd, zijn overgeslagen. De reden hiervoor was zowel van praktische aard (beperkte ruimte en afnametijd) als van inhoudelijke aard (er werd verwacht dat de IWPV vragen voldoende priming zouden bieden).

Hoewel de auteurs van de HPQ aangegeven hebben dat het mogelijk is om deze vragen apart af te nemen, ${ }^{23}$ is er bij ons geen informatie bekend over de validiteit van de afname van alleen deze twee vragen. Tevens is een langere terugvraagperiode dan de standaard 4 weken van de HPQ gebruikt in de huidige studie, om vergelijkbaarheid tussen de HPQ en IWPV te vergroten, en om te voorkomen dat deelnemers meerdere keren van terugvraagperiode moesten veranderen tijdens het invullen van de vragenlijsten.

Een andere mogelijke verklaring voor de zwakkere relatie is dat de IWPV zich richt op daadwerkelijke prestatie (wat iemand normaal gesproken doet), terwijl de HPQ vraagt naar de eigen werkprestatie ten opzichte van de best mogelijke werkprestatie (wat iemand maximaal kan doen). Door dit subtiele verschil zouden de twee constructen minder vergelijkbaar kunnen zijn dan vooraf verwacht, en zijn de gevonden matige correlaties wellicht verklaarbaar. Tevens is vanuit methodologisch perspectief de score van één vraag onbetrouwbaarder dan de score gebaseerd op een multi-item instrument. ${ }^{24}$ Daarnaast reflecteert één algemene vraag wellicht niet goed het gehele spectrum van individuele gedragingen die relevant zijn voor werkprestatie. De gedragingen of acties die 
werknemers in gedachten hebben wanneer ze hun algemene werkprestatie beoordelen, kan verschillen tussen personen, en kan substantieel anders zijn dan wat onderzoekers als relevante aspecten van individuele werkprestatie beschouwen. Zo bleek bijvoorbeeld dat de contraproductieve schaal zwak correleerde met de eigen beoordeling van de algehele werkprestatie. Dit suggereert dat mensen amper hun contraproductieve gedragingen in acht nemen, wanneer ze hun algehele werkprestatie beoordelen. De IWPV geeft al met al een meer compleet en generiek beeld van individuele werkprestatie, met informatie over de verschillende dimensies van individuele werkprestatie (een 'profiel').

Zoals verwacht bleek er een zwakke samenhang te zijn tussen de IWPV score en de relatieve werkprestatie score (eigen werkprestatie ten opzichte van die van collega's). Deze zwakke samenhang was niet verrassend, aangezien de IWPV niet aan een werknemer vraagt om de eigen werkprestatie te beoordelen ten opzichte van die van een collega, terwijl dit wel de focus is van relatief presenteïsme gemeten met de HPQ. Daarnaast kan het voor werknemers onprettig zijn om de werkprestatie van hun collega's te beoordelen, of hebben ze misschien geen collega's die vergelijkbaar werk doen. ${ }^{25}$

Zoals verwacht bleek er over het algemeen een matige samenhang te zijn tussen IWP en werkbevlogenheid. Daarmee duidt het huidige onderzoek op een redelijk goede convergente validiteit van de IWPV, en bevestigt het de positieve relatie tussen werkbevlogenheid en werkprestatie die in veel eerdere onderzoeken is gevonden. ${ }^{26-28}$ Interessant is dat bevlogenheid de sterkste relatie heeft met contextuele prestatie. Bevlogen werknemers lijken hun team of organisatie dus vooral ten goede te komen doordat zij meer extra-rol gedragingen vertonen, zoals extra verantwoordelijkheden op zich nemen, actief meedoen in overleg, en nieuwe mogelijkheden aangrijpen.

Zoals verwacht bleken de IWPV scores te verschillen tussen relevante groepen. Dit duidt op een goede discriminante validiteit van de IWPV. Hiermee bevestigt het huidige onderzoek tevens de positieve relaties tussen zowel werktevredenheid en werkprestatie, als gezondheid en werkprestatie. Dit sluit aan bij eerder onderzoek, waaruit is gebleken dat zowel tevreden werknemers, ${ }^{29,30}$ als gezonde werknemers ${ }^{31,32}$ een betere werkprestatie vertonen. Deze bevindingen ondersteunen tevens het idee dat tevreden, gezonde werknemers ook productieve werknemers zijn. ${ }^{33,34}$

\section{Normering en gebruik}

In het huidige onderzoek worden normscores voor de IWPV per type werk gepresenteerd. De IWPV levert drie scores op: per schaal van de IWPV wordt één score gegeven. Het berekenen van één totaalscore over de drie schalen is niet toegestaan. Dit heeft ten eerste een methodologische reden, omdat somscores alleen opgeteld mogen worden binnen een unidimensionele schaal. ${ }^{35}$ Ten tweede wordt er vanuit inhoudelijk oogpunt veel informatie verloren over de afzonderlijke dimensies van IWP wanneer men de schaalscores optelt.
We merkten eerder op dat de IWPV een generiek instrument is. Daarmee bedoelden we dat voor ieder type werk dezelfde vragen gesteld kunnen worden. Tijdens de ontwikkeling van de IWPV bleek echter dat sommige vragen een verschillende 'moeilijkheid' hebben per type werk. Dit fenomeen heet "differential item functioning" (DIF) ${ }^{36}$ Het betekent dat mensen met een bepaald type werk makkelijker 'hoog' scoren op een bepaalde vraag dan mensen met een ander type werk. Zo is het bijvoorbeeld voor mensen die mentaal werk uitvoeren, gemakkelijker om hoog te scoren op de vraag "Hield ik resultaten in gedachten" dan voor mensen die fysieke werk hebben. Dit betekent echter niet dat mensen met fysieke werkzaamheden een lagere taakprestatie hebben. In de normering van de IWPV schaalscores wordt rekening gehouden met deze DIF. Daarom is ook normering van de scores per type werk gewenst.

Door de aanwezigheid van DIF moet men voorzichtig zijn met vergelijkingen tussen verschillende typen werk, en dient men hierbij rekening te houden met de verschillende normeringen. Door ons streven om van de IWPV een generiek instrument te maken, bevat het geen beroepsspecifieke vragen en is daarom minder geschikt voor gebruik in individuele beoordelingen, functioneringsgesprekken en/of feedback.

Door zijn generieke aard is de IWPV uitermate geschikt voor onderzoek waarin werknemers geïncludeerd zijn met verschillende typen werk (zoals organisatie brede of nationale enquêtes). Een groot voordeel van de IWPV is dat bijvoorbeeld in onderzoek binnen een bedrijf met verschillende typen werk, dezelfde vragenlijst aan alle werknemers voorgelegd kan worden. Tevens kan de IWPV op een betrouwbare manier elk niveau van werkprestatie meten, van een laag niveau van werkprestatie (bijvoorbeeld bij werknemers met gezondheidsklachten) tot een hoog niveau van werkprestatie (bijvoorbeeld bij toppresteerders). Hierdoor is de IWPV ook geschikt om veranderingen in IWP te detecteren bij werknemers - ook werknemers die al een goede werkprestatie hebben - bijvoorbeeld als gevolg van interventies op de werkvloer.

\section{Beperking}

Een beperking van de IWPV is de aanwezigheid van vloereffecten in de schaal die contraproductief werkgedrag beoogt te meten. Dit betekent dat verdere verbeteringen in contraproductief werkgedrag (dus: het vertonen van minder contraproductief werkgedrag) door ingezette interventies moeilijk meetbaar kunnen zijn. De lage scores op contraproductief werkgedrag zouden als volgt verklaard kunnen worden. Ten eerste is het verre van onwaarschijnlijk dat de aanwezigheid van contraproductief werkgedrag op de werkvloer daadwerkelijk laag is. Ten tweede kan de schaal sociaal wenselijke antwoorden oproepen: werknemers zouden terughoudend kunnen zijn met toegeven dat zij zich contraproductief gedragen op het werk.

\section{Toekomstig onderzoek}

Het valideren van een meetinstrument is een continu proces, en toekomstig onderzoek zal zich moeten blijven 
richten op het verzamelen van bewijs voor de validiteit van de IWPV. Wij raden andere onderzoekers dan ook aan om de IWPV te gaan gebruiken in onderzoek. Een praktische handleiding voor het praktisch gebruik en scoring van de IWPV in onderzoek is op verzoek verkrijgbaar bij de auteurs.

We hebben in dit onderzoek de test-hertest betrouwbaarheid van de IWPV nog niet onderzocht. In vervolgonderzoek moet onderzocht worden of personen de vragen in de IWPV als deze een week of twee later weer ingevuld wordt hetzelfde zouden beantwoorden. Ten tweede is interessant om de validiteit van de IWPV verder te onderzoeken door deze ook in andere onderzoekspopulaties te correleren met presenteïsme, werkbevlogenheid, werktevredenheid en gezondheid. Het is interessant om verder inzicht te krijgen in de werking van de IWPV binnen specifieke groepen, zoals lage SES-groepen of specifieke beroepen. Ten derde is het interessant om de relatie van de IWPV met andere constructen te testen, zoals de beoordeling van collega's en de manager (360 graden feedback), en objectieve uitkomsten, zoals data van ziekteverzuim en kosten. Ten vierde is het interessant om de predictieve validiteit van de IWPV te onderzoeken: welke voorspellende waarde hebben de schaalscores ten opzichte van relevante criteria in de toekomst, bijvoorbeeld beoordelingen door leidinggevenden en/of het toekennen van periodieken? Ten vijfde zal de gevoeligheid voor verandering van de IWPV moeten worden getest, waarbij ook aandacht is voor de interpretatie van verschilscores. Wat is het kleinste verschil dat de IWPV kan detecteren, en wanneer is een verandering relevant? Tot slot is het interessant om verder te onderzoeken hoe voorspellers de verschillende dimensies van werkprestatie beïnvloeden. Het valt bijvoorbeeld te verwachten dat verschillende voorspellers verschillend gerelateerd zijn aan de dimensies van individuele werkprestatie (zoals in het huidige onderzoek is aangetoond voor werkbevlogenheid).

\section{CONCLUSIE}

De IWPV biedt onderzoekers een valide instrument om individuele werkprestatie op een gestandaardiseerde en generieke manier te meten. De belangrijkste voordelen van de IWPV zijn dat deze alle relevante dimensies van IWP meet, generiek toepasbaar is voor werknemers uit verschillende beroepssectoren en werknemers met en zonder gezondheidsproblemen, en kort met slechts 18 vragen. Gebruik van de IWPV zal meer inzicht kunnen bieden in het hele spectrum van individuele gedragingen die werkprestatie bepalen en haar voorspellers, de vergelijkbaarheid tussen studies ten goede komen, en zicht geven op de effectiviteit van interventies gericht op het in stand houden of verbeteren van IWP.

\section{ABSTRACT}

The Individual Work Performance Questionnaire (IWPQ): internal consistency, construct validity, and norm scores Measuring individual work performance, defined as "behaviors or actions of employees that are relevant to the goals of the organization", is challenging. So far, there was no suitable questionnaire to measure individual work performance in a generic, mostly healthy, working population. The current article introduces the Individual Work Performance Questionnaire (IWPQ). The IWPQ is based on a conceptual framework with three dimensions: task performance, contextual performance, and counterproductive work behavior. The factor structure and internal consistency of the IWPQ subscales, as well as the construct validity of the IWPQ, appear to be good. Norm scores per type of work are presented. The IWPQ provides researchers with a reliable and valid instrument to measure the full spectrum of individual work performance, in a standardized and generic way (for workers in all types of jobs, and workers with and without health problems).

Keywords: employee performance appraisal, productivity, measurement, questionnaire, scales

\section{LITERATUUR}

1. Dalal RS. A meta-analysis of the relationship between organizational citizenship behavior and counterproductive work behavior. J Appl Psychol 2005;90:1241-55.

2. Rotundo M, Sackett PR. The relative importance of task, citizenship, and counterproductive performance to global ratings of performance: a policy-capturing approach. J Appl Psychol 2002;87:66-80.

3. Campbell JP. Modeling the performance prediction problem in industrial and organizational psychology. In: Dunnette MD, Hough LM (Eds). Handbook of industrial and organizational psychology, Vol.1 (2nd ed.). Palo Alto, CA, US: Consulting Psychologists Press, 1990:687-732.

4. Austin JT, Villanova P. The criterion problem: 1917-1992. J Appl Psychol 1992;77:836-74.

5. Koopmans L, Bernaards CM, Hildebrandt VH, De Vet HCW, van der Beek AJ. Measuring Individual Work Performance: Identifying and Selecting Indicators. Work: J Prevent Assess Rehab 2013;45;229-38.

6. Koopmans L, Bernaards CM, Hildebrandt VH et al. Conceptual frameworks of individual work performance - A systematic review. J Occup Environ Med 2011;53:856-66.

7. Viswesvaran C, Ones DS. Perspectives on Models of Job Performance. Int J Select Assess 2000;8:216-26.

8. Borman WC, Motowidlo SJ. Expanding the criterion domain to include elements of contextual performance. In: Schmitt N, Borman WC (eds). Personnel Selection in Organizations. San Francisco, CA: Jossey Bass, 1993:71-98.

9. Williams LJ, Anderson SE. Job satisfaction and organizational commitment as predictors of organizational citizenship and inrole behaviors. J Management 1991;17:601-17.

10. Organ DW PP, MacKenzie SB. Organizational Citizenship Behavior: Its Nature, Antecedents, and Consequences. London: Sage Publications, 2006.

11. Bennett RJ, Robinson SL. Development of a Measure of Workplace Deviance. J Appl Psychol 2000;85:349-60.

12. Reilly MC, Zbrozek AS, Dukes EM. The Validity and Reproducibility of a Work Productivity and Activity Impairment Instrument. Pharmacoeconomics 1993;4:355-65.

13. Lerner D, Amick BC, Rogers WH et al. The Work Limitations Questionnaire. Med Care 2001;39:72-85.

14. Kessler RC, Barber C, Beck A et al. The World Health Organi- 
zation Health and Work Performance Questionnaire (HPQ). J Occup Environ Med 2003;45:156-74.

15. Lofland JH, Pizzi L, Frick KD. A Review of Health-Related Workplace Productivity Loss Instruments. Pharmacoeconomics 2004;22:165-84.

16. Mattke S, Balakrishnan A, Bergamo G, Newberry SJ. A Review of Methods to Measure Health-related Productivity Loss. Am J Managed Care 2007;13:211-8.

17. Koopmans L, Bernaards CM, Hildebrandt VH et al Development of an Individual Work Performance Questionnaire. Int J Product Perform Management 2013;62:6-28.

18. Koopmans L, Bernaards CM, Hildebrandt VH. Improving the Individual Work Performance Questionnaire using Rasch Analysis. J Appl Measurement 2014;15:160-75.

19. Rasch G. Probabalistic Models for Some Intelligence and Attainment Tests: Chicago: University of Chicago Press, 1960.

20. Cronbach IJ. Coefficient alpha and the internal structure of tests. Psychometrika 1951;16:297-333.

21. Mokkink LB, Terwee CB, Patrick DL et al. The COSMIN study reached international consensus on taxonomy, terminology, and definitions of measurement properties for health-related patient-reported outcomes. J Clin Epidemiol 2010;63:737-45.

22. Schaufeli WB, Bakker AB, Salanova M. The Measurement of Work Engagement With a Short Questionnaire: A Cross-National Study. Educ Psychol Measur 2006;66:701-16.

23. Kessler RC, Petukhova M, McInnes K, Ustun TB. Content and Scoring Rules for the WHO HPQ absenteeism and presenteeism questions. To: Persons interested in the WHO HPQ absenteeism and presenteeism questions, 2007.

24. Vet HCW de, Terwee CB, Mokkink LB, Knol DL. Measurement in Medicine: Cambridge University Press, 2011.

25. Bernaards CM, Proper KI, Hildebrandt VH. Physical Activity, Cardiorespiratory Fitness, and Body Mass Index in Relationship to Work Productivity and Sickness Absence in Computer Workers With Preexisting Neck and Upper Limb Symptoms. J Occup Environ Med 2007;49:633-40.

26. Bakker AB, Schaufeli WB, Leiter MP, Taris TW. Work Engagement: An Emerging Concept in Occupational Health Psychology. Work Stress 2008;22:187-200.
27. Demerouti E, Cropanzano R. From Thought to Action: Employee Work Engagement and Job Performance. In: Bakker AB, Leiter MP, editors. Work Engagement: A Handbook of Essential Theory and Research. New York: Psychology Press, 2010.

28. Halbesleben JRB, Wheeler AR. The Relative Roles of Engagement and Embeddedness in Predicting Job Performance and Intention to Leave. Work \& Stress. 2008;22(3):242-56.

29. Harrison DA, Newman DA, Roth PL. How important are job attitudes? Meta-analytic comparisons of integrative behavioral outcomes and time sequences. Acad Management J 2008;49: 305-25.

30. Judge TA, Bono JE, Thoresen CJ, Patton GK. The Job Satisfaction-Job Performance Relationship: A Qualitative and Quantitative Review. Psychol Bull 2001;127:376-407.

31. Boles $M$, Pelletier B, Lynch W. The Relationship Between Health Risks and Work Productivity. J Occup Environ Med 2004;46: 737-45.

32. Schultz $A B$, Edington DW. Employee Health and Presenteeism: A Systematic Review. J Occup Rehab 2007;17:547-79.

33. Fischer $C D$. Why do lay people believe that satisfaction and performance are correlated? Possible sources of a commonsense theory. J Organ Behav 2003;24:753-77.

34. Staw BM. Organizational Psychology and the Pursuit of the Happy/Productive Worker. Cal Manag Rev 1986;XXVIII(4): 40-53.

35. Velde G van der, Beaton D, Hogg-Johnston S, Hurwitz E, Tennant $A$. Rasch Analysis Provides New Insights Into the Measurement Properties of the Neck Disability Index. Arthrit Rheum 2009;61:544-51.

36. Tennant A, McKenna SP, Hagell P. Application of Rasch Analysis in the Development and Application of Quality of Life Instruments. Value in Health 2004;7:S22-S6.

\section{CORRESPONDENTIEADRES}

Dr. Claire Bernaards, TNO, Postbus 2215, Leiden, tel. 0888666067, e-mail: claire.bernaards@tno.nl. 